Original Research Article

\title{
Factors determining adoption of bean quality improvement practices by cocoa farmers in Cross River State, Nigeria
}

\author{
Abdulrazak Kamal Daudu ${ }^{2}$, Felix Olayinka Oladipo ${ }^{2}$, Kayode Samson Balogun ${ }^{1}$, \\ Olabisi Adebowale Awoniyi ${ }^{1}$, Rashid Solagberu Adisa ${ }^{2}$ \\ ${ }^{1}$ Lower Niger River Basin Development Authority, Ilorin, Kwara State, Nigeria \\ ${ }^{2}$ Department of Agricultural Extension and Rural Development, University of Ilorin, Ilorin, Nigeria \\ Correspondence to: \\ K.S. Balogun, Lower Niger River Basin Development Authority, Ilorin, Kwara State, Nigeria, \\ e-mail: kaypearl2006@yahoo.com
}

\begin{abstract}
Persistent drop in quality of Nigerian cocoa exported to the international communities portends a grave danger to the economy of the country. This study investigates factors determining adoption of bean quality improvement practices by cocoa farmers in Cross River State, Nigeria. Using a two-stage random sampling technique to select 336 farmers from communities with high production, data were collected with a structured questionnaire and subjected to factor analysis and descriptive statistical procedures. The data revealed that majority of the respondents (66.1\%) were male with mean age of 48 years, $78.6 \%$ were formally educated whereas 31.0\% had a quarterly contact with extension agents. Most of the respondents (98.2\%) had high perception on practices considered as being adequate for improving the quality of cocoa beans. There was a positive and significant relationship between perception on cocoa bean quality and adoption of bean quality improvement practices $(r=0.142$ and $p=0.001)$ at one percent level of significance. Factor analysis showed that socioeconomic, production, technological and institutional factors with Eigenvalues of 3.312, 2.403, 1.862 and 1.055, respectively, accounted for the quality of cocoa beans. However, educational level of farmers (0.867), cost of inputs $(-0.724)$, relative advantage of the practice $(0.683)$ and contact with extension agents (0.703) exert greater influence on farmers' capacity to produce quality cocoa beans. The identified variables should therefore be considered when disseminating improved practices to cocoa farmers for increased adoption.
\end{abstract}

Keywords: Theobroma cacao; quality; determinant factors; farmers; questionnaire; Cross River State

\section{INTRODUCTION}

Over-dependence on oil and the global decline of oil prices have been a major concern to the Nigerian government in terms of economic stability (Amodu, 2018). Cocoa has been seen as a viable alternative to crude oil exploration as it has been adjudged to be a strategic commodity for national development if harnessed properly (International Cocoa Organization, ICCO, 2018). Though Nigeria still commands an appreciable share of the cocoa produced from the
African continent, evidence over the years had shown a decline in annual output, thereby giving rise to a fall in the fortune of the sub-sector (ICCO, 2016). This was consequent upon the closure of the Nigerian Cocoa Marketing Board in the 1980s after which the government's involvement in the cocoa sub-sector was greatly reduced and premium quality was no more rewarded (Adelodun, 2017). Earnings from cocoa exports had also gone down in recent times as observed in 2019 when the country recorded export revenue of

(C) AUTHORS 2021.

This work is licensed under the Creative Commons Attribution-NonCommercial-NoDerivs 4.0 License (https://creativecommons.org/licenses/by-nc-nd/4.0/) 
US\$248.5 million depicting a drop of 3.0\% from 2018 figure mainly due to the exportation of low-quality cocoa beans (Workman, 2020).

Cross River State is strategic to the federal government's plan of achieving the zero-oil initiative in Nigeria (Agro Business News, 2015). This was clearly spelt out in the economy diversification policy of the current government in which agriculture is a key. Ejiofor and Ashang (2017) opined that over-dependency of the State's economy on federal government allocation from petroleum and the fall in crude oil prices in the international market constitute the most recent threat to agricultural production in the State. As a road-map to economic freedom, the State government has begun to look inward into developing its versed agricultural opportunities by targeting export crops like cocoa. The State is also one of the beneficiaries of the Federal Government/Central Bank of Nigeria co-sponsored Anchor Borrowers' Programme established to make funds readily available to rural farmers in order to maximise agricultural production. Cross River State farmers are versed in cocoa production, accounting for about $30 \%$ of the national total annual production (Bloomberg, 2016). The State also harbours relatively younger cocoa trees which are generally more productive with ages ranging between 11 and 40 years (Balogun, 2019). Despite the huge potentials of cocoa in stimulating agricultural growth in the State, it is surprising to note that cocoa production has been going on a descending trend (Tiku et al., 2016). The inability to fully tap the production potentials is an indication that there is a structural defect within the production system. Such uncertainty in the production of a very important export crop like cocoa calls for a great concern and gives threatening signals to the realisation of the sustainability potentials of the industry.

The International Cocoa Organization (ICCO) explained that the quality requirements for cocoa beans can only be met by sound cultivation, as well as good post-harvest practices (ICCO, 2017). Actors in the cocoa sector therefore have been provided with best practices that can improve the quality of cocoa beans both for export and local use. Some of these practices are contained in a manual published at the end of the nineteenth meeting of the consultative Board on World Cocoa Economy which took place in Moscow in 2009. According to the manual, cocoa of merchant quality must be properly fermented, thoroughly dry, free from smoky beans, free from abnormal or foreign odours and free from any evidence of adulteration. In addition, high quality cocoa beans must be uniform in size, reasonably free from broken beans, fragments and pieces of shell, and be virtually free from foreign matter. Sadly, past studies had shown farmers' reluctance in using some of these practices probably because they are time-consuming and cost-intensive, and are generally seen as prioritising quality over quantity of which the latter has been cocoa producers' primary target (Fadipe et al., 2012; Alamu, 2013; Omoare et al., 2016). The International Institute for Tropical Agriculture asserted that Nigerian cocoa farmers produce beans of low quality due to their adherence to primordial production practices and non-compliance to the international specifications (IITA, 2017).

Several factors have been found to play key role in cocoa farmers' decision to adopt improved production practices. Quarmine et al. (2012) found that lack of information on quality standards and the practices required to comply with the standards passed on from purchasing agents to farmers constrained them from adopting improved cocoa production practices in Ghana. As shown by Baffoe-Asare et al. (2013), age, household size and social capital are important factors influencing cocoa farmers' decision to adopt pest and disease management practices in Ghana. Farm gate price, farm size, property ownership, rural infrastructures are key determinants of sustainable cocoa production in Northern Haiti, as shown by Wegbert (2015). Onu (1991) cited in Opara (2010) asserted that the socio-economic characteristics of farmers have great influence on their adoption behaviour whereas Nmadu et al. (2015) argued that cultural, political and geographical variables as well as the characteristics of an innovation also play a fundamental role in the decision of a potential adopter. It therefore becomes pertinent to carry out a qualitative study that can encompass the subjective reasoning behind farmers' decision to adopt relevant practices required for improving the quality of cocoa beans they produce. We hypothesised that the production of quality cocoa beans can be achieved when farmers are well informed about the benefits and costs associated with bean quality improvement practices. The objective of this study was therefore to evaluate farmers' perception on the characteristics of bean quality improvement practices and analyse the variables associated with production of quality cocoa beans in the study area.

\section{MATERIALS AND METHODS}

The study was carried out in Cross River State, Nigeria. The State lies between latitudes $4^{\circ}$ and $5^{\circ}$ North of the equator and longitudes $7^{\circ}$ and $9^{\circ}$ East of the Greenwich Meridian. It shares boundary with Benue State to the West, Abia State to the South and the Atlantic Ocean 
to the East. Humid tropical climate of 1300-3000 mm rainfall and $30{ }^{\circ} \mathrm{C}$ mean annual temperature prevail over the State except on the Obudu Plateau where the climate is sub-temperate with temperatures of $15^{\circ} \mathrm{C}-23^{\circ} \mathrm{C}$. The vegetation ranges from Mangrove Swamps, through rainforests to derived Savannah and Montane Parkland. The total land area of the State is 23,074 square kilometers distributed over 18 Local Government Areas (LGAs). The State has a projected population of 3.3 million people (NPC, 2011), spread across three agricultural zones, namely southern, northern and central. Food crops such as rice, cassava, soybean and maize, and tree crops like cocoa, oil-palm, banana and plantain are grown in the State. Cocoa is mainly produced in the southern and central zones of the State.

A two-stage sampling procedure was used to obtain the sample size for the study. Stage one involved purposive selection of twenty-four rural communities with high level of production spread across the three major cocoa producing Local Government Areas (LGAs) of Cross River State. These LGAs are Ikom, Etung and Boki. The communities selected in Ikom LGA are Ikom, Yaunde, Bendeghe Afi, Akam, Okuni, Okondi, Otutop and Akparabong. The communities selected in Etung LGA are Ajassor, Bendeghe Ekiem, Agbokim, Abia, Etomi, Effraya, Itaka and Abijang. The communities selected in Boki LGA are Abu Police, Orimekpang, Wula, Abontakon, Orimekpang Inland, Iso-Bendeghe, Okundi and Bumaji. Stage two involved random selection of fourteen farmers per community to give a total of 336 respondents used for the study analysis. Data for the study were collected from the respondents using structured questionnaire and focus group discussion. The questionnaire had three sections A to C, covering the three objectives of the study. Section A covered the socioeconomic characteristics of respondents and consisted of questions about the respondents' age, level of education, household size, farming experience, farm size and farm income. Section B covered extension services delivery to respondents and contained questions about respondents' sources of information on bean quality improvement practices and the frequency of extension contact. Section $C$ covered the perception of respondents on bean quality improvement practices and consisted of sixteen statements about the characteristics of the bean quality improvement practices and respondents' opinion rated on a 5-point Likert scale of strongly agree, agree, undecided, disagree and strongly disagree. A single focus group methodology was adopted for the study. This was conducted separately in each of the three major cocoa producing LGAs harbouring the twenty-four communities selected. A twelve-member group comprising nine males and three females was purposively selected across each of the LGAs through the help of the farmers' heads and experienced extension workers in the respective LGAs thus putting the total number of farmers involved in the focus group discussion at thirty-six. A convenient date was picked and a conducive venue was also chosen. Factors considered in the choice of venue include proximity to the group members, space and serenity to command maximum concentration. The group discussion had a moderator, an assistant, a recorder and an analyst. These personnel had undergone relevant trainings. The discussion lasted for about an hour to avoid fatigue. Topics discussed include stock selection, shade management, fermentation, drying, storage and marketing of cocoa beans. The obtained data were analysed using statistical tools such as mean, frequency counts and standard deviations, Pearson product moment correlation and factor analysis. The software used for the study's statistical data evaluation was SPSS (IBM) since it offers the ability to easily compile descriptive statistics as well as graphical depictions of results through the graphical user interface (GUI).

\section{Measurement of variables}

The independent variables include the socioeconomic characteristics of respondents measured as age in years, farming experience in years, household size as number of farmer and dependants, income level in naira and farm size in hectares.

To evaluate the respondents' perception on bean quality improvement practices, 20 perception statements were listed. A 5-point Likert-type scale with values of strongly agree $=5$, agree $=4$, undecided $=3$, disagree $=2$ and strongly disagree $=1$ was used to determine the respondents' level of agreement to these statements. These values were added to obtain 15 which was divided by 5 to get a mean score of 3.0. A mean score of $\geq 3.00$ indicated high perception whereas a mean score of $<3.00$ indicated low perception.

The index of respondents' perception on bean quality improvement practices was obtained from the statements used to ascertain the perception. Twenty statements were used with a maximum score of 100 and a minimum score of 20 based on the Likert scale used. This gave a mid-point value of 60 . All scores below this mid-point (20-60) were tagged as the percentage of farmers with low perception, while all scores above this mid-point (61-100) were tagged as the percentage of farmers with high perception. 


\section{Use of factor analysis}

The methodology used for this study was adapted from Adisa and Adekunle (2010). Factor analysis is used mainly when one is interested in knowing whether some underlying pattern or relationship exist among variables; discovering a new set of factors; or confirming (an) existing factor(s) as being the true factor(s) (Kleinbaum and Kupper, 1978). In factor analysis, a priori identification of factors is not a pre-requisite and the researcher thus uses factor analysis to characterise meaningful factors that could validly describe the data. The result of the analysis is usually in the form of a matrix where the derived factors form the columns and the original variables constitute the rows (Jimoh and Olorunfemi; 2005). Because the variables in the adoption of cocoa bean quality improvement practices are several, the factors were subjected to oblique rotation. This is so because of the need to ensure that all variables are ascribed to a factor, and none is allocated to two or more factors. The scale items included in factor analysis usually have five or seven categories.

\section{RESULTS AND DISCUSSION Socioeconomic characteristics of respondents}

The results of the socioeconomic characteristics of respondents revealed that mean age of respondents was 48 years. This implies that majority of the respondents were close to their 50s which is an indication of the ageing population in cocoa farming in the study area. This may discourage the uptake of bean quality improvement practices by cocoa farmers since older farmers do not easily retract from tradition and are more risk-averse than younger farmers (Kassie et al., 2013) thereby suggesting the production of low-quality cocoa beans. About thirty-three percent (32.7\%) of the respondents had secondary education. Following closely was tertiary education (31.3\%). This implies that more graduates are now involved in cocoa cultivation which may likely spur the adoption of bean quality improvement practices when proper structures are put in place. This result did not align with earlier finding by Oluyole and Sanusi (2009) who reported less graduates' involvement in cocoa farming in the study area. The mean household size of the respondents was 7 people. This implies that farmers had fairly large household size which could possibly serve as insurance against short falls in supply of farm labour. However, labour-demanding practices like pruning, agrochemical application, harvesting, pod breaking and sorting are cost-intensive and this could discourage farmers from adoption due to reduction in propensity to save which invariably could lead to food insecurity in the household (Melesse, 2018). The mean duration of experience of the respondents in cocoa farming was 17.5 years. This implies that respondents have been farming for a considerable period of time. This could be disadvantageous to uptake of bean quality improvement practices due to the high recognition ascribed to longevity in farming by rural farmers. This result agrees with the earlier submission of Uwagboe et al. (2016) that majority of the cocoa farmers in Cross River State have been farming for about two decades. The average farm size of the respondents was 2.2 hectares. This implies that cocoa cultivation is still in the hands of small-scale farmers. This result aligns with the report of Omoare et al. (2016) that majority of cocoa farmers in Southwestern Nigeria are smallholders cultivating less than 10 hectares of farmland. The average income generated by the respondents from cocoa sale per hectare was N637, 721. This figure seems high, however, cocoa farmers during group discussion argued that the figure is low when compared to total costs they incurred during production. The seemingly low income generated could be as a result of the farmers' reluctance to adopt improved practices that could have improved the quality of cocoa they produced. The result corroborates earlier assertion by Adeogun et al. (2015) that income generated by farmers from cocoa sale was low in Cross River State, Nigeria.

\section{Extension services delivery to respondents}

It is discernable from the results of the extension services delivery to respondents that almost all of the respondents, $97.0 \%$ and $93.8 \%$ sourced the information from fellow farmers, friends and neighbours, respectively. This suggests that there might be some level of closeness and trust among the farmers. It was further revealed that $76.2 \%$ and $57.1 \%$ of the respondents got information on bean quality improvement practices from Cocoa Association of Nigeria (CAN) and Cocoa Farmers Association of Nigeria (CFAN), respectively, whereas half of the respondents (50.0\%) explored the media outlets. The least sources of information were Agricultural Development Programme extension agents (42.9\%), cocoa certification agencies (39.6\%) and Cocoa Research Institute of Nigeria (36.9\%). This result aligns with the submission of Omoare et al. (2016) that Cocoa Research Institute of Nigeria was a rare source of information to cocoa farmers on cocoa quality improvement practices in Southwest Nigeria, even though it is a public agricultural extension agency. A total of $31.0 \%$ respondents indicated that they had contact with the extension agents once every 3 months, $29.8 \%$ had contact once in a year, $23.2 \%$ had contact once in a month, $15.2 \%$ had contact once every 2 weeks, and 
Table 1. Distribution of respondents by socioeconomic characteristics ( $\mathrm{n}=336$ )

\begin{tabular}{|c|c|c|c|c|}
\hline \multicolumn{2}{|c|}{ Socioeconomic characteristics } & \multirow{2}{*}{$\frac{\text { Frequency }}{15}$} & \multirow{2}{*}{$\frac{\text { Percentage }}{4.5}$} & Mean ( \pm SD) \\
\hline \multirow{5}{*}{ Age (Years) } & $\leq 30$ & & & \multirow{5}{*}{$48.2 \pm 9.7$} \\
\hline & $31-40$ & 84 & 25.0 & \\
\hline & $41-50$ & 125 & 37.2 & \\
\hline & $51-60$ & 68 & 20.2 & \\
\hline & $>60$ & 44 & 13.1 & \\
\hline \multirow{5}{*}{ Level of education } & No education & 49 & 14.6 & \\
\hline & Adult education & 23 & 6.8 & \\
\hline & Primary education & 49 & 14.6 & \\
\hline & Secondary education & 110 & 32.7 & \\
\hline & Tertiary education & 105 & 31.3 & \\
\hline \multirow{4}{*}{$\begin{array}{l}\text { Household size } \\
\text { (number of farmer } \\
\text { and dependants) }\end{array}$} & $1-5$ & 147 & 43.8 & \multirow{4}{*}{$7.0 \pm 3.0$} \\
\hline & $6-10$ & 167 & 49.7 & \\
\hline & $11-15$ & 18 & 5.3 & \\
\hline & $>15$ & 4 & 1.2 & \\
\hline \multirow{4}{*}{$\begin{array}{l}\text { Farming experience } \\
\text { (Years) }\end{array}$} & $\leq 10$ & 15 & 4.5 & \multirow{4}{*}{$17.5 \pm 5.8$} \\
\hline & $11-20$ & 249 & 74.1 & \\
\hline & $21-30$ & 63 & 18.8 & \\
\hline & $>30$ & 9 & 2.6 & \\
\hline \multirow{3}{*}{$\begin{array}{l}\text { Size of cocoa farm } \\
\text { (Hectares) }\end{array}$} & $\leq 1.9$ & 189 & 56.3 & \multirow{3}{*}{$2.2 \pm 1.3$} \\
\hline & $2.0-3.0$ & 122 & 36.3 & \\
\hline & $>3$ & 25 & 7.4 & \\
\hline \multirow{4}{*}{$\begin{array}{l}\text { Income from cocoa } \\
\text { (Naira/hectare }\end{array}$} & $\leq 250$ & 2 & 0.6 & \multirow{4}{*}{$637,721.9 \pm 93,919.9$} \\
\hline & $251-500$ & 13 & 3.9 & \\
\hline & $501-750$ & 294 & 87.5 & \\
\hline & $>750$ & 27 & 8.0 & \\
\hline
\end{tabular}

Source: Field survey, 2018, SD = Standard Deviation

Table 2. Distribution of respondents by extension services received ( $\mathrm{n}=336)$

\begin{tabular}{|c|c|c|}
\hline \multicolumn{3}{|l|}{ Extension services delivery to cocoa farmers } \\
\hline Sources of information & Frequency & Percentage* $^{*}$ \\
\hline ADP extension agents & 144 & 42.9 \\
\hline Cocoa Research Institute of Nigeria (CRIN) & 124 & 36.9 \\
\hline Cocoa Farmers' Association of Nigeria (CFAN) & 192 & 57.1 \\
\hline Media (radio, television, prints and ICTs) & 168 & 50.0 \\
\hline Licensed Buying Agents (LBAs) & 160 & 47.6 \\
\hline Cocoa certification agencies/organizations & 133 & 39.6 \\
\hline Fellow farmers & 326 & 97.0 \\
\hline Friends and neighbours & 315 & 93.8 \\
\hline Cocoa Association of Nigeria (CAN) & 256 & 76.2 \\
\hline Contact with extension agents & Frequency & Percentage \\
\hline Weekly & 3 & 0.8 \\
\hline Fortnightly & 51 & 15.2 \\
\hline Monthly & 78 & 23.2 \\
\hline Quarterly & 104 & 31.0 \\
\hline Yearly & 100 & 29.8 \\
\hline
\end{tabular}

Source: Field survey, $2018,{ }^{*}$ Multiple responses 
very few $(0.8 \%)$ had contact with the extension agents once every week. The highest frequency of extension contact occurred once every three months which indicates that extension agents did not visit cocoa farmers regularly. This may be a disincentive to farmers from adopting the improved practices for bean quality improvement.

\section{Perception on bean quality improvement practices by respondents}

Perception is expected to play an important role in farmers' decision to adopt a new production practice. Using the mean score and standard deviation to rank the order of perception, use of improved variety of cocoa improves cocoa flavour $(4.76 \pm 0.43)$ was ranked $1^{\text {st. }}$ This is an indication that farmers considered the flavour of their cocoa bean to have a direct link to the planting material they cultivated in their farms thereby aligning with the submission of Agambedu (2012) that flavour characteristic in cocoa is partly inherent in parent stock. It was further revealed that statements such as adequate shading in cocoa reduces pest attack $(4.64 \pm 0.58)$ and appropriate dose of fertiliser enhances plant growth (4.60 \pm 0.59$)$ ranked $2^{\text {nd }}$ and $3^{\text {rd }}$, respectively. This implies that farmers realised the relevance of shade management and fertiliser application to the production of quality cocoa beans. Essentially, mean scores for the perception statements about the bean

Table 3. Distribution of respondents by perception on bean quality improvement practices $(\mathrm{n}=336)$

\begin{tabular}{|c|c|c|c|c|c|c|c|}
\hline \multirow[b]{2}{*}{ Bean quality improvement practices } & \multicolumn{7}{|c|}{ Respondents' opinion } \\
\hline & $\begin{array}{l}\text { Strongly } \\
\text { agree } \\
(\%)\end{array}$ & $\underset{(\%)}{\text { Agree }}$ & $\begin{array}{c}\text { Undecided } \\
(\%)\end{array}$ & $\begin{array}{c}\text { Disagree } \\
(\%)\end{array}$ & $\begin{array}{c}\text { Strongly } \\
\text { disagree } \\
(\%)\end{array}$ & Mean ( \pm SD) & Rating \\
\hline $\begin{array}{l}\text { Use of improved variety improves cocoa } \\
\text { flavour }\end{array}$ & 75.9 & 24.1 & 0 & 0 & 0 & $4.76 \pm 0.43$ & $1^{\text {st }}$ \\
\hline $\begin{array}{l}\text { Adequate shading in cocoa reduces pest } \\
\text { attack }\end{array}$ & 67.6 & 30.7 & 0 & 1.8 & 0 & $4.64 \pm 0.58$ & $2^{\text {nd }}$ \\
\hline $\begin{array}{l}\text { Appropriate dose of fertilizer enhances } \\
\text { plant growth }\end{array}$ & 64.0 & 34.2 & 0 & 1.8 & 0 & $4.60 \pm 0.59$ & $3^{\text {rd }}$ \\
\hline Field pests and diseases reduce bean quality & 58.9 & 37.5 & 0 & 1.8 & 1.8 & $4.50 \pm 0.76$ & $10^{\text {th }}$ \\
\hline $\begin{array}{l}\text { Timely pruning encourages growth of good } \\
\text { sized pods }\end{array}$ & 64.6 & 31.8 & 0 & 1.8 & 1.8 & $4.56 \pm 0.75$ & $5^{\text {th }}$ \\
\hline Overripe pods produce germinated beans & 54.8 & 43.4 & 0 & 1.8 & 0 & $4.51 \pm 0.59$ & $8^{\text {th }}$ \\
\hline $\begin{array}{l}\text { Inclusion of damaged and diseased pods } \\
\text { reduce bean quality }\end{array}$ & 54.2 & 44.0 & 0 & 1.8 & 0 & $4.51 \pm 0.50$ & $9^{\text {th }}$ \\
\hline $\begin{array}{l}\text { Delay in pod breaking causes disease } \\
\text { infection }\end{array}$ & 53.0 & 45.2 & 0 & 1.8 & 0 & $4.49 \pm 0.60$ & $11^{\text {th }}$ \\
\hline $\begin{array}{l}\text { Fermenting beans not covered from rain } \\
\text { and/or cold become mouldy }\end{array}$ & 52.7 & 45.5 & 0 & 1.8 & 0 & $4.49 \pm 0.59$ & $12^{\text {th }}$ \\
\hline $\begin{array}{l}\text { Over- or under-fermentation reduces cocoa } \\
\text { flavour }\end{array}$ & 59.8 & 38.4 & 0 & 1.8 & 0 & $4.56 \pm 0.59$ & $6^{\text {th }}$ \\
\hline $\begin{array}{l}\text { Inadequate turning of fermenting beans } \\
\text { reduces cocoa flavour }\end{array}$ & 56.5 & 39.9 & 0 & 1.8 & 1.8 & $4.48 \pm 0.76$ & $13^{\text {th }}$ \\
\hline $\begin{array}{l}\text { Beans dried on a raised slab above the } \\
\text { ground surface are free of foreign materials }\end{array}$ & 51.5 & 46.7 & 0 & 1.8 & 0 & $4.48 \pm 0.60$ & $14^{\text {th }}$ \\
\hline Inadequate drying produces mouldy beans & 49.7 & 48.5 & 1.8 & 0 & 0 & $4.48 \pm 0.53$ & $15^{\text {th }}$ \\
\hline $\begin{array}{l}\text { Inclusion of damaged beans and pebbles } \\
\text { increases impurities in bagged beans }\end{array}$ & 58.6 & 39.6 & 1.8 & 0 & 0 & $4.57 \pm 0.53$ & $4^{\text {th }}$ \\
\hline $\begin{array}{l}\text { Beans of uniform size in the same bag } \\
\text { facilitates bean counting and grading }\end{array}$ & 45.2 & 53.0 & 0 & 1.8 & 0 & $4.42 \pm 0.59$ & $20^{\text {th }}$ \\
\hline $\begin{array}{l}\text { Use of clean jute bags prevents bean } \\
\text { contamination and pest attack }\end{array}$ & 54.2 & 42.2 & 0 & 3.6 & 0 & $4.47 \pm 0.68$ & $16^{\text {th }}$ \\
\hline $\begin{array}{l}\text { Beans stored directly on ground surface } \\
\text { become wet }\end{array}$ & 48.5 & 49.7 & 1.8 & 0 & 0 & $4.47 \pm 0.53$ & $17^{\text {th }}$ \\
\hline $\begin{array}{l}\text { Strong odours reduce flavour of the stored } \\
\text { beans }\end{array}$ & 52.4 & 44.0 & 0 & 1.8 & 1.8 & $4.43 \pm 0.75$ & $19^{\text {th }}$ \\
\hline $\begin{array}{l}\text { Adequate store ventilation prevents bean } \\
\text { mouldiness }\end{array}$ & 57.7 & 40.5 & 0 & 1.8 & 0 & $4.54 \pm 0.59$ & $7^{\text {th }}$ \\
\hline Store pests and diseases reduce bean quality & 47.0 & 51.2 & 1.8 & 0 & 0 & $4.45 \pm 0.53$ & $18^{\text {th }}$ \\
\hline
\end{tabular}

Source: Field survey, 2018; Mean score $<3.0$ (low perception); Mean score $\geq 3.0$ (high perception) 
quality improvement practices considered in this study showed that farmers perceived all of the practices to be adequate for the production of quality cocoa beans. This suggests that cocoa farmers in the study area are not new in cocoa farming and therefore have great potential to produce cocoa beans of global acceptability.

\section{Perception index of respondents on bean quality improvement practices}

The results of the perception index of respondents on bean quality improvement practices revealed that majority (98.2\%) of the respondents had a high perception level on bean quality improvement practices. On the other hand, very few (1.8\%) had a low perception level on the improved practices. The implication of high perception level is that most of the cocoa farmers in the study area will be ready to make use of relevant practices that can bring about improvement in the quality of beans they produce which invariably will also improve their income and living conditions. Additionally, the cocoa farmers will be ready to participate in any training that will improve their production capacity particularly in terms of quality assurance thereby improving their personal income and the country's revenue at large through cocoa export.

\section{Factor analysis of variables in production of quality cocoa beans}

The first output in factor analysis is the results of extraction of component factors among farmers in the sample with their respective Eigenvalues and percentages of variance. Five factors, namely socioeconomic, production, technological, institutional and environmental were anticipated based on the tested variables. Factors with Eigenvalues greater than 1.0 were used in further analysis. It was revealed that only Factors 1-4 (socioeconomic, production, technological and institutional factors) had Eigenvalues greater than 1.0, as the fourth factor represents $89.2 \%$ of the variance in the data. Factor 5, that is, environmental factors, with an Eigenvalue of 0.448 and $10.8 \%$ of variance were thus excluded from further analysis. This indicates that environmental variables were not significant variables in the production of quality cocoa beans in the study area.

Using Kaiser's rule of thumb which says that variables with coefficients 0.3 and above may be used to name a factor, variables with high loadings are age (-0.320), educational level (0.867); household size (-0.709); farm income (0.453) and farming experience (0.861). Since all these variables are socioeconomic, the first factor was thus named as 'Socioeconomic Factors'. The age of the farmers had a negative influence on production of quality cocoa beans. This implies that the older the farmer, the lesser the likelihood of producing quality cocoa beans. This could be attributed to the fact that older farmers are more inclined to tradition and culture so they prefer to practice what they had learnt over the years. This finding affirms the assertion of Melesse (2018) that age had a negative relationship with the adoption of new agricultural technologies in Ethiopia. Farming experience of cocoa farmers showed positive correlation with production of quality cocoa beans. This implies that farmers with longer years of experience are more likely to adopt bean quality improvement practices. This result aligns with the finding of Omoare et al. (2016) that farming experience was positively significant to the adoption of cultural management practices among cocoa farmers in the southwestern part of Nigeria. Education also showed positive significant correlation. This implies that farmers with higher level of education will likely embrace the idea of adopting bean quality improvement practices, thus increasing likelihood of producing quality cocoa beans. This finding corroborates the submission of Uwagboe et al. (2016) that education was positively correlated to adoption of Integrated Pest Management (IPM) practices in Cross River State of Nigeria. There was a negative significant relationship between the number of people living in the household and production of quality cocoa beans. This implies that farmers who have large household size may not be willing to adopt the improved practices required for producing quality cocoa beans as a result of higher financial commitment. This finding disagrees

Table 4. Extraction of component factors $(n=336)$

\begin{tabular}{lccc}
\hline Factors & Eigenvalues & Percentage (\%) of variance & $\begin{array}{c}\text { Cumulative percentage (\%) of } \\
\text { variance }\end{array}$ \\
\hline Socioeconomic & 3.312 & 35.06 & 35.06 \\
Production & 2.403 & 20.92 & 55.98 \\
Technological & 1.862 & 18.46 & 74.44 \\
Institutional & 1.055 & 14.80 & 89.24 \\
Environmental & 0.448 & 10.76 & 100.00 \\
\hline
\end{tabular}

Source: Field survey, 2018 
with that of Adesiyan et al. (2019) who reported that a positive relationship exists between household size and the adoption of cocoa input technologies among women cocoa farmers in Osun State of Nigeria. Farm income, influencing capital, which in turn determines farm size, had a positive sign. The implication is that higher farm income increases the likelihood of adopting the (costly) improved practices required for producing quality cocoa beans. This finding supports the assertion of Adesiyan et al. (2019) that low-income farmers in Osun State of Nigeria produce low quality cocoa beans.

Under the second factor, the variables loading high are high cost of farm inputs (-0.724), labour-intensive (-0.685), farm size (0.719) and pests and diseases (-0.722). Factor 2 was thus termed 'Production Factors' because the four factors loading under it are all production-related. High cost of farm inputs presents a potential for production of low-quality cocoa beans as it was found to have an inverse correlation. Farmers are generally discouraged from purchasing costly inputs such as pesticides and fungicides which could have averted farm crisis such as pests and disease infestation that could further lower the quality of beans produced.
Labour-consuming operations like planting, spraying, pruning, harvesting, pod breaking among others could be associated with reduction in cocoa bean quality when labour is not readily available. Hence, labour-intensive showed an inverse correlation. Farm size, which may increase due to cultivation of new lands showed positive correlation. This implies that an increase in farm size could increase the potential for producing quality cocoa beans since farmers with large farms may have spare land to try new practices, and this may facilitate adoption when favourable results are obtained. This result aligns with the report of Kayode et al. (2017) that farm size was significantly associated with land management practices in Kogi State of Nigeria.

Under the third factor, the variables loading are relative advantage of improved practices (0.683), compatibility with existing practice (0.629) and simplicity of the improved practices (0.515). Since these three variables are technology-related, they are thus named 'Technological Factors'. The positive correlation for these variables indicates that an increase in the variables could improve the quality of cocoa beans produced. This implies that benefits accrued from an

Table 5. Oblique rotated factor component correlations (factor loading)

\begin{tabular}{|c|c|c|c|c|}
\hline Variables & $\begin{array}{c}\text { Socioeconomic } \\
\text { factors }\end{array}$ & $\begin{array}{c}\text { Production } \\
\text { factors }\end{array}$ & $\begin{array}{c}\text { Technological } \\
\text { Factors }\end{array}$ & $\begin{array}{c}\text { Institutional } \\
\text { factors }\end{array}$ \\
\hline Age of cocoa farmers & -0.320 & -0.003 & 0.013 & 0.037 \\
\hline Education & 0.867 & -0.067 & 0.037 & -0.048 \\
\hline Age of cocoa tree & 0.258 & 0.003 & 0.031 & -0.053 \\
\hline Household size & -0.709 & -0.008 & 0.030 & -0.035 \\
\hline High cost of farm input & 0.007 & -0.724 & -0.026 & -0.089 \\
\hline Labour intensive & 0.252 & -0.685 & -0.083 & 0.044 \\
\hline Cocoa farm size & 0.013 & 0.719 & 0.130 & 0.341 \\
\hline Income & 0.453 & 0.219 & 0.015 & 0.062 \\
\hline Farming experience & 0.861 & 0.078 & 0.052 & 0.026 \\
\hline Relative advantage of improved practices & 0.029 & -0.042 & 0.683 & -0.208 \\
\hline Unpredictable climate conditions & 0.093 & -0.024 & -0.044 & 0.101 \\
\hline Far distance to the nearest market & 0.013 & 0.020 & -0.107 & -0.411 \\
\hline Compatibility with existing practice & -0.012 & 0.041 & 0.629 & -0.230 \\
\hline Sources of information & 0.045 & 0.266 & 0.178 & $2.15 \mathrm{E}-02$ \\
\hline Inadequate storage structures & -0.019 & -0.055 & 0.418 & 0.047 \\
\hline Inadequate technical know-how & 0.007 & -0.029 & 0.426 & 0.017 \\
\hline Contact with extension agents & -0.005 & 0.335 & 0.092 & 0.703 \\
\hline Access to credit & -0.005 & 0.357 & -0.031 & 0.577 \\
\hline Pests and diseases & -0.005 & -0.722 & -0.046 & -0.033 \\
\hline Simplicity of the improved practices & 0.025 & 0.250 & 0.515 & -0.167 \\
\hline Traditional practices & -0.058 & -0.047 & 0.029 & -0.050 \\
\hline Cultural beliefs & $1.119 \mathrm{E}-03$ & 0.106 & 0.326 & -0.026 \\
\hline Land tenure & 0.010 & -0.006 & 0.012 & -0.074 \\
\hline Social participation & -0.021 & -0.062 & 0.044 & 0.597 \\
\hline Government policy & 0.025 & 0.004 & 0.126 & 0.219 \\
\hline
\end{tabular}

Source: Field survey, 2018 
Table 6. Results of correlation analysis showing relationship between farmers' perception on cocoa bean quality and adoption of quality improvement practices

\begin{tabular}{lcc}
\hline & Correlations & Farmers' perception on cocoa bean quality \\
\hline & Pearson Correlation & $0.142^{* *}$ \\
Adoption of bean quality & Sig. (2-tailed) & 0.001 \\
improvement practices & Sum of Squares and Cross-products & 19.362 \\
& Covariance & 0.046 \\
\hline
\end{tabular}

**. Correlation is significant at the 0.01 level (2-tailed).

Source: Field survey (2018)

improved practice, its fitness into the prevailing farming system and the ease at which it can be carried out could be associated with the production of quality cocoa beans in consistence with the work of Omoare et al. (2016) and Uwagboe et al. (2016).

Under Factor 4, named 'Institutional Factors', the variables with high loadings are far distance to the nearest market $(-0.411)$, contact with extension agents (0.703), access to credit (0.577) and social participation (0.597). Consistent with the submission of Quarmine et al. (2012) that absence of information on improved technologies in cocoa production could be associated with reduction in bean quality, contact with extension agents showed positive correlation, perhaps implying that extension contact could contribute to the improvement in cocoa bean quality. This also means that when cocoa farmers are visited by the extension agents on a regular basis, there is a high tendency for these farmers to have wealth of relevant information that could transform into the production of quality cocoa beans. Far distance to the nearest market could also reduce the tendency to produce quality cocoa beans in consistence with Tefera et al. (2016). Thus, the factor is inversely correlated. This implies that farmers whose farms are far to the nearest market may be denied vital information on bean quality assurance and thus have high potential of producing beans of low quality. Social participation and access to credit, influencing farm capital, could contribute to the improvement of cocoa bean quality. These two variables had a positive correlation. The implication is that belonging to a social organisation raises the tendency for cocoa farmers to access credit (loans), thus increasing their capability to acquire the resources required for producing quality beans. This result agrees with the submission of Kolade and Harpham (2014) and Nunoo et al. (2014) that cooperative membership is de facto determining the quality of cocoa beans in Nigeria and Ghana, respectively.

\section{Testing of hypothesis}

$\mathbf{H}_{\mathbf{0}}$ : There is no significant relationship between the farmers' perception on cocoa bean quality and adoption of bean quality improvement practices.
Results of correlation analysis on the relationship between farmers' perception on cocoa bean quality and adoption of bean quality improvement practices showed that there was positive and significant relationship between perception on cocoa bean quality and adoption of bean quality improvement practices $(\mathrm{r}=0.142$ and $p=0.001)$ at 1 percent level of significance. This finding suggests that increase in the farmers' perception on the quality of cocoa beans would result in increased adoption of bean quality improvement practices and change of farmers' perception. Hence, the null hypothesis was therefore rejected and the alternate accepted. This finding also implies that benefits accrued from adoption of improved practice, its fitness into the prevailing farming system and the ease at which it can be carried out could be associated with the production of quality cocoa beans in consistence with the submission of Omoare et al. (2016) and Uwagboe et al. (2016).

\section{CONCLUSIONS AND RECOMMENDATIONS}

We investigated factors determining adoption of bean quality improvement practices by cocoa farmers in Cross River State, Nigeria. The obtained data showed that more graduates are now involved in cocoa cultivation in the study area, whereas adults still dominate in terms of labour capacity. Extension agents have not been visiting cocoa farmers regularly as public agricultural extension organisations were poorly accessed for information on cocoa bean quality improvement practices. The major factors associated with cocoa bean quality are socio-economic, production, technological and institutional while variables of major influence include farmers' education, high cost of inputs, relative advantage of the practice and extension contact.

Drawing from the findings of this study, the following recommendations are made:

- The presence of older cocoa farmers in the study area is an indication that the future of cocoa production is in danger as this could have negative impact on cocoa productivity. Therefore, youths should be encouraged to take up cocoa farming as a profession through the 
provision of social amenities in the communities and granting of soft loans.

- Opportunities in the mass media extension communication channels, especially the print method, and the Information and Communication Technologies (ICTs) should be fully explored to update cocoa farmers in the study area about bean quality improvement practices since most of them are literates.

- The National Anchor Borrowers' Programme should be strengthened and properly monitored for export crops like cocoa in order to provide financial supports to producers.

- There is a critical need for effective public agricultural extension services delivery; hence Ministry of Agriculture need to organise a special agricultural extension service for farmers and also improved extension contact for proper monitoring in the use of improved practices that can enhance the production of quality cocoa beans.

- Government and other relevant agencies should make farm inputs readily available to cocoa farmers at subsidised rates. A reasonable reduction in their prices will enable the prospective users acquire and use them for their respective purposes.

\section{CONFLICT OF INTEREST}

The authors declared no conflicts of interest with respect to research, authorship and publication of this article.

\section{ETHICAL COMPLIANCE}

The authors have followed the ethical standards in conducting the research and preparing the manuscript.

\section{REFERENCES}

Adelodun A. (2017): Cocoa production in Nigeria: A literature review. The Centre for Public Policy Alternatives (CPPA) Publication, Lagos, Nigeria. http://www.cpparesearch.org. (Accessed on January 18, 2019)

Adeogun S. O., Fapojuwo E. O., Oyeyinka R. A., Adamu C. O., Abiona B.J. (2015): Training needs assessment of cocoa farmers' association members on soil management techniques in Cross River State of Nigeria. Ethiopian Journal of Environmental Studies and Management 6: 551-560.

Adesiyan O. F., Adesiyan A. T., Agbonlahor M. (2019): Adoption of cocoa input technologies under agricultural transformation Agenda among women cocoa farmers in Ile-Ife, Osun State. Journal of Development and Agricultural Economics 11: 52-56.

Adisa R. S., Adekunle O. A. (2010): Farmers-herdsmen conflict: A factor analysis of socio-economic conflict variables among arable crop farmers in North Central Nigeria. Journal of Human Ecology 30: 1-9.

Agambedu A. (2012): Maintaining quality standards in the face of internet market competition in Ghana's cocoa industry: A case study of Offinso Municipality. A Masters' Thesis submitted to the Institute of Distance Learning, Kwame Nkrumah University of Science and Technology, Ghana. http://hdl.handle. net/123456789/4246. (Accessed on December 23, 2018)

Agro Business Nigeria (2015): Agriculture opportunities in Cross River State. Published by Legends and Genius Limited, 2015. http://agrobusinessng.com/ agriculture-opportunities-in-cross-river-state. (Accessed May 27, 2018)

Alamu S. A. (2013): Analysis of seedling subsidy policy and cocoa production in Southwest Nigeria. Journal of Educational and Social Research 3: 59-68.

Amodu O. B. (2018): Overdependence of Nigerian economy on crude oil, the implications and the solutions. A Master's Thesis (MBA) submitted to the Department of International Business, School of Business and Governance, Tallinn University of Technology, Estonia. http://www.semanticscholar. org. (Accessed on January 4, 2019)

Baffoe-Asare R., Danquah J. A., Annor-Frempong F. (2013): Socio-economic factors influencing adoption of Codapec and Cocoa High-tech Technologies among small holder farmers in Central Region of Ghana. American Journal of Experimental Agriculture 3: 277-292.

Balogun K. S. (2019): Adoption of standard practices for cocoa export among farmers in Cross River State, Nigeria. A Ph.D. Thesis submitted to the Department of Agricultural Extension and Rural Development, University of Ilorin, Ilorin, Nigeria.

Bloomberg (2016): Nigeria's Cross River state to expand cocoa land, boost export. An article written by Tolani Awere and published in the Bloomberg, $15^{\text {th }}$ February, 2016. https://www.bloomberg.com/newa/ articles/2016-02-15/nigeria-s-cross-river-state-toexpand-cocoa-land-boost-output. (Accessed on December 29, 2018)

Ejiofor T. E., Ashang M. U. (2017): Repositioning cocoa production in northern agricultural zone of Cross River State for economic revitalization. A Paper presented at $25^{\text {th }}$ National Conference on Repositioning Technical and Vocational Education 
for Post-oil boom economy held on $13^{\text {th }}-16^{\text {th }}$ June, 2017 at Unical International Conference Center, University of Calabar, Calabar, Cross River State.

Fadipe A. E. A., Adenuga A. H., Ilori T. E. (2012): Economic analysis of cocoa production in Oyo State, Nigeria. Nigeria Journal of Agriculture, Food and Environment 8: 58-63.

International Cocoa Organization (2016): Production of cocoa beans. Quarterly Bulletin of Cocoa Statistics, London. http://www.icco.org. (Accessed on January 3, 2019)

International Cocoa Organization (2017): Production of cocoa beans. Quarterly Bulletin of Cocoa Statistics, London. http://www.icco.org. (Accessed on January 3, 2019)

International Cocoa Organization (2018): Production of cocoa beans. Quarterly Bulletin of Cocoa Statistics, London. http://www.icco.org. (Accessed on January 3, 2019)

International Institute for Tropical Agriculture (2017): USAID Nigeria Expanded Trade and Transport (NEXTT) - Cocoa close-out meeting and strategic thinking, IITA News. http://www.belletin.iita.org/ index.php/20. (Accessed on January 5, 2019)

Jimoh A., Olorunfemi J. A. (2005): Methods of data analysis in social sciences. In: Saliu H. A., Oyebanji J. O., Jimoh A. (Eds): Basic issues in research methodology. Unilorin: FBSS pp. 70-93.

Kassie M., Jaleta M., Shiferaw B., Mmbando F., Mekuria M. (2013): Adoption of interrelated sustainable agricultural practices in smallholder systems: Evidence from rural Tanzania. Technological Forecasting and Social Change, Elsevier 80: 525-540.

Kayode A. O., Oladipo F. O., Daudu A. K. (2017): Determinants of adoption of land management practices in Kogi State, Nigeria: A gender analysis. Journal of Tropical Agriculture, Food, Environment and Extension 16: 52-58.

Kleinbaum D. G., Kupper L. L. (1978): Applied regression analysis and other multivariate methods. North Scitvate Massachusetts: Duxbury Press, pp. 12-413.

Kolade O., Harpham T. (2014): Impact of cooperative membership of farmers' uptake of technological innovations in Southwest Nigeria. Development Studies Research. DOI: 10.1080/21665095.2014.978981

Melesse B. (2018): A review of factors affecting adoption of agricultural new technologies in Ethiopia. Journal of Agricultural Science and Food Research 9: 1-4.

Nmadu J. N., Sallawu H., Omojeso B. V. (2015): Socio-economic factors affecting adoption of innovations by cocoa farmers in Ondo State, Nigeria. European Journal of Business, Economics and Accountancy 3: 58-66.

Nunoo I., Frimpong N., Frimpong F.K. (2014): Fertilizer use among cocoa farmers in Ghana. The case of Sefwi Wiawso District. International Journal of Environment 3: 22-31.

Oluyole K. A., Sanusi R. A. (2009): Socio-Economic Variables and Cocoa Production in Cross River State, Nigeria. Journal of Human Ecology 25: 5-8.

Omoare A. M., Oyediran W. O., Fakoya E. O. (2016): Comparative assessment of cocoa farmers' knowledge and attitude to trainings on good cultural management practices (CMP) in Ogun and Ondo States, Nigeria. International Journal of Agricultural Extension and Rural Development Studies 3: 36-51.

Opara U. N. (2010): Personal and Socio-Economic Determinants of Agricultural Information Use by Farmers in the Agricultural Development Programme (ADP) Zones of Imo State, Nigeria. Library Philosophy and Practice (e-journal), University of Nebraska - Lincoln.https:// digitalcommons.uni.edu/libphilprac/434. (Accessed on May 13, 2020)

Quarmine W., Haagsma R., Sakyi-Dawson O., Asante F., van Huis A., Obeng-Ofori D. (2012): Incentives for cocoa bean production in Ghana: Does quality matter? NJAS - Wageningen Journal of Life Sciences 60: 7-14.

Tefera T., Tesfay G., Elias E., Diro M., Koomen I. (2016): Drivers for adoption of agricultural technology and practices in Ethiopia. http://www.cascape.info. (Accessed on February 18, 2019)

Tiku N. E., Galadima M., Iyala D. (2016): Scale efficiency of cocoa production in Cross River State, Nigeria. FUW Trends in Science \& Technology Journal 1: 417-422.

Uwagboe E. O., Meludu N. T., Agbebaku E. E. O. (2016): Adoption of Integrated Pest Management among Cocoa Farmers in Cross River and Osun States of Nigeria. Journal of Agricultural Extension 5: 188-201.

Wegbert C. (2015): Factors influencing sustainable cocoa production in Northern Haiti. M.Sc. Thesis submitted to the Department of Agricultural Economics and Agribusiness, Louisiana State University and Agricultural \& Mechanical College, Haiti.

Workman D. (2020): Nigeria's top 10 exports. http:// www.worldstopexports.com. (Accessed on May 20, 2020)

Received: April 16, 2019 Accepted after revisions: March 4, 2021 